\title{
QUANTIFICATION OF TOTAL CHROMIUM AND HEXAVALENT CHROMIUR: IN WATER BY ELECTROTHERMAL ATOMIC ABSORPTION SPECTROMETRY
}

\author{
B.S. Jayasinghe', M.I.F.P. Jayawardene' \& K.A.S.Pathiratne 2 \\ Department of Biochemistry, Faculty of Medical Sciences, \\ University of Sri Jayewardenepura \\ 2Department of Chemistry, University of Kelaniya
}

The two primary oxidation states of chromium in natural waters, $\mathrm{Cr}(\mathrm{III})$ and $\mathrm{Cr}(\mathrm{VI})$, differ significantly in biological, geochemical and toxicological propertics. Whereas $\mathrm{Cr}$ (III) is considered essential for human in glucose, lipid and protein metabolism, $\mathrm{Cr}(\mathrm{VI})$ is toxic because of its ability to oxidize other species and its adverse effects on the lung, liver and kidney. Because of the different toxicities and bioavailability of $\mathrm{Cr}(\mathrm{III})$ and $\mathrm{Cr}(\mathrm{VI})$, determination of the total chromium content does not give full information about possible health hazard. Hence monitoring of the concentration of the separate chromium species is of great importance. Many different techniques have been in use for $\mathrm{Cr}$ containing samples preparation and metal ions speciation: ion chromatography, flow injection analysis, and atomic absorption spectrometry (AAS).

Procedures for the quantification of total chromium and hexavalent chromium in water samples are presented. For the quantification of total chromium and hexavalent chromium in water Chromabond $\mathrm{NH}_{2}$ columns (aminopropyl phase with a $3 \mathrm{ml}$ volume and $500 \mathrm{mg}$ of sorbent) obtained from Machery- Nagel (Duren, Germany) wcre used.

The $\mathrm{pH}$ value of the water sample was adjusted to 5.5 using acetic acid or sodium acetate and sample was aspirated through the previously conditioned column. The column contents were dried under vacuum and the hexavalent chromium selectively linked was eluted with nitric acid and quantification was performed by Electrothermal Atomic Absorption Spectrometry (ETAAS). For the detection of total chromium, $\mathrm{Cr}$ (III) was transformed into $\mathrm{Cr}(\mathrm{VI})$ by oxidizing the sample with $1 \% \mathrm{~K}_{2} \mathrm{~S}_{2} \mathrm{O}_{8}$ solution and $\mathrm{AgNO}_{3}$ at $100^{\circ} \mathrm{C}$ for 15 min. Oxidized solution was elutcd through a Chromabond column and total $\mathrm{Cr}$ lcvel was quantified by ETAAS using the same instrumental conditions as for hexavalent chromium. Total chromium was also quantificd directly in the water samples using ETAAS. The temperature programme of the graphite furnace, the use of chemical modifiers, the atomic technique employed and the effectiveness of deutcrium background correction were investigated. Chromium was reliably determined by without chemical modifiers or background correction.

The detection limits were 0.4 and $0.5 \mu \mathrm{g} / \mathrm{l}$ for total chromium and hexavalent chromium respectively. The linearity changed under the optimized conditions was $0.4-50 \mu \mathrm{g} / 1$ and $0.5-50 \mu \mathrm{g} / 1$ and the relative standard deviation was less than $3.5 \%$. The validation of both procedures was performed by the standard addition method and the recoveries were higher than $96 \%$ in all cases. It is proved that the method can be successfully employed as an alternative to the commonly used preconcentration and speciation analytical techniques. The direct procedure was adopted for the estination of total clromium in water samples because both procedures applied for total chromium gave similar results. The methods were applied to the determination of total chromium and hexavalent chromium in 40 water samples.

Proceedings of the Eighth Annual Forestry and Environment Symposium 2002 of the Department of Forestry and Environmental Science, University of Sri Jayewardenepura, Sri Lanka 